\title{
THE ECONOMICS OF MICROHYDRO POWER PLANTS
}

\author{
KH. S. KARIMOV ${ }^{1,2}$, M. ABID ${ }^{1}$, M.W. AL-GRAFI ${ }^{3}$, S.I. ISLOMOV ${ }^{4}$ \\ AND N.H. KARIMOVA ${ }^{4}$ \\ ${ }^{I}$ GIK Institute of Engineering Sciences and Technology, Topi, Pakistan. \\ ${ }^{2}$ Physical Technical Institute of Academy of Sciences, Tajikistan. \\ ${ }^{3}$ Department of Mechanical Engineering, Taibah University, \\ Al-Madina Al-Munawara, Saudi Arabia. \\ ${ }^{4}$ Institute of Economics of Academy of Sciences of Tajikistan, Dushanbe, Tajikistan.
}

khasan@giki.edu.pk,abid@giki.edu.pk

\begin{abstract}
This paper appraises the Economics of renewable energy and the hydropower systems on the basis of two countries namely Tajikistan and Pakistan. The economics of a micro-hydropower plant installed in the village named Pashmi-Kuhna of Tajikistan and of a battery-based micro-hydropower plant on catamaran for free water flow operation designed, fabricated and tested in GIK Institute of Pakistan are discussed in this paper. For the economic evaluation of these power plants, the life-cycle costing approach is used. Finally, the costs of the produced energy by the micro-hydropower plants are calculated.
\end{abstract}

ABSTRAK: Menerusi kertas kerja ini, bidang ekonomi loji hidrokuasa mikro yang dibina di perkampungan Pashmi-Kuhna, Tajikistan diperbincangkan. Loji hidrokuasa mikro di atas katamaran yang membolehkan gerakan air bebas berasaskan bateri direka, dicipta dan diuji di Institut Pakistan GIK. Untuk penilaian ekonomi loji ini, pendekatan pengekosan kitar hidup telah digunakan. Akhirnya, kos dihitung berdasarkan kuasa yang dihasilkan oleh loji hidrokuasa mikro.

KEYWORDS: Micro-Hydro; Power Plants; Economics; Life-Cycle Costing; Annualized Life-Cycle Cost.

\section{INTRODUCTION}

Economics of renewable energy and, in particular, of hydropower systems are described in detail in [1-10]. The cost of the micro-hydropower system depends on a number of factors including costs of equipment, transportation and preparation of the necessary documents concerning the conditions of area, head (water level), flow rate, type and class of the micro-hydropower system [1]. Usually the cost of the station is in the range of US\$ $1500-2500$ for $1 \mathrm{~kW}$ of installed power. Depending on the power and location the cost of micro-hydropower system of power less than $5 \mathrm{~kW}$ is approximately US\$ 2500 for $1 \mathrm{~kW}$ [1]. It seems costly as the power produced is low, but in this cost calculation, the cost of batteries is included.

If the head is higher and flow rate is lower, then the cost of the station is less than the case of lower head and higher flow rate. This is due to the lower costs and smaller sizes of water pipes and turbine in the case of high head and low flow rate. The cost of microhydropower system depends on quality and quantity of equipments and materials that will be used for the project, and of the cost of construction of powerhouse, laying of pipes and other factors. If the work will be done by the contractor, then the total cost of microhydropower system will be higher with respect to the case when these works are done by the owner of the station. The project of every micro-hydropower system is unique. At the 
same time it is observed that $25 \%$ of the cost of equipment is the cost of the electromechanical equipment, and $75 \%$ of all the expenses depend on the location of the system and condition of the micro-hydropower system [1]. In this work, the economics of the micro-hydropower plants (MHP) installed in the village named Pashmi-Kuhna of Tajikistan and of the battery-based micro-hydropower plant on catamaran for free water flow operation designed, fabricated and tested in GIK Institute of Pakistan are discussed [5].

\section{ECONOMICS OF MICRO-HYDROPOWER PLANT INSTALLED IN THE VILLAGE PASHMI-KUHNA OF TAJIKISTAN}

A micro-hydropower plant manufactured by Turbine Constructing Industrial Union "Leningrad Metallic Plant" [11] was selected and installed by Karimov U.Kh. and Karimov Kh.S. Table 1 shows technical parameters of this micro-hydropower system. In this micro-hydropower system, a three-phase asynchronous generator (4A100L2y3) with squirrel-cage-type rotor is used. The stator of the generator is delta-connected, with maximum power of $5.5 \mathrm{~kW}$ and synchronous rotation velocity of rotor of $3000 \mathrm{RPM}$. The shaft of the propeller turbine was connected directly to the shaft of the generator. Excitation of generator is made by 30 capacitors (10 pieces for each phase) with capacitance of $10 \mathrm{mF}$ each, which are installed in the voltage regulator BARS-004.

Table 1: Technical parameters of the micro-hydropower plant manufactured by

"Leningrad Metallic Plant" [11-13].

\begin{tabular}{ll}
\hline Head, $\mathrm{m}$ & 4 to 10 \\
Flow rate, liter/second & 75 to 83 \\
Electric power, $\mathrm{kW}$ & 0.5 to 4.0 depending on the head \\
Number of phase & 3 \\
Nominal output voltage, $\mathrm{V}$ & 220 \\
Frequency, Hz & 50 \\
Mass, kg & \\
- Power block, kg & 97 \\
- Voltage regulator BARS-004, kg & 50 \\
Water inlet hose-pipe, $\mathrm{kg}$ & 15 \\
\hline
\end{tabular}

This micro-hydropower system was installed in a remote mountain village named Pashmi-Kukhna situated in the national park "Shirkent" in Tursun-zoda district. Due to the absence of the roads for automobile, all equipments including plastic pipes was transported by the beast of burden (donkeys) for a distance of around $30 \mathrm{~km}$. Microhydropower system was installed on the derivative canal from river Shirkent. Water current power was calculated to be almost $8-12 \mathrm{~kW}$ in the derivative canal by the estimation of head and flow rate using well known approaches described in [11]. The MHP was installed close to the village houses, and by using short transmission lines (100$300 \mathrm{~m}$ ), electical power is supplied from station to the houses (Fig.1).

In order to achieve the required water head, plastic pipes of internal diameter $0.19 \mathrm{~m}$ and length of $5.5 \mathrm{~m}$ were fixed at an angle of 45 degree to the horizontal surface. Several pipes were joined by winding two layers; one of rubber and other of firm rubber cloth and then joints were fixed with metallic horse collar. It was important to fix the energy block 
(generator and turbine) well. This was done using ropes and stones on two sides of the generator and turbine. In order to clean water from sand and stones, a small settling basin of size $3 \times 3 \times 1.5 \mathrm{~m}^{3}$ was also constructed.
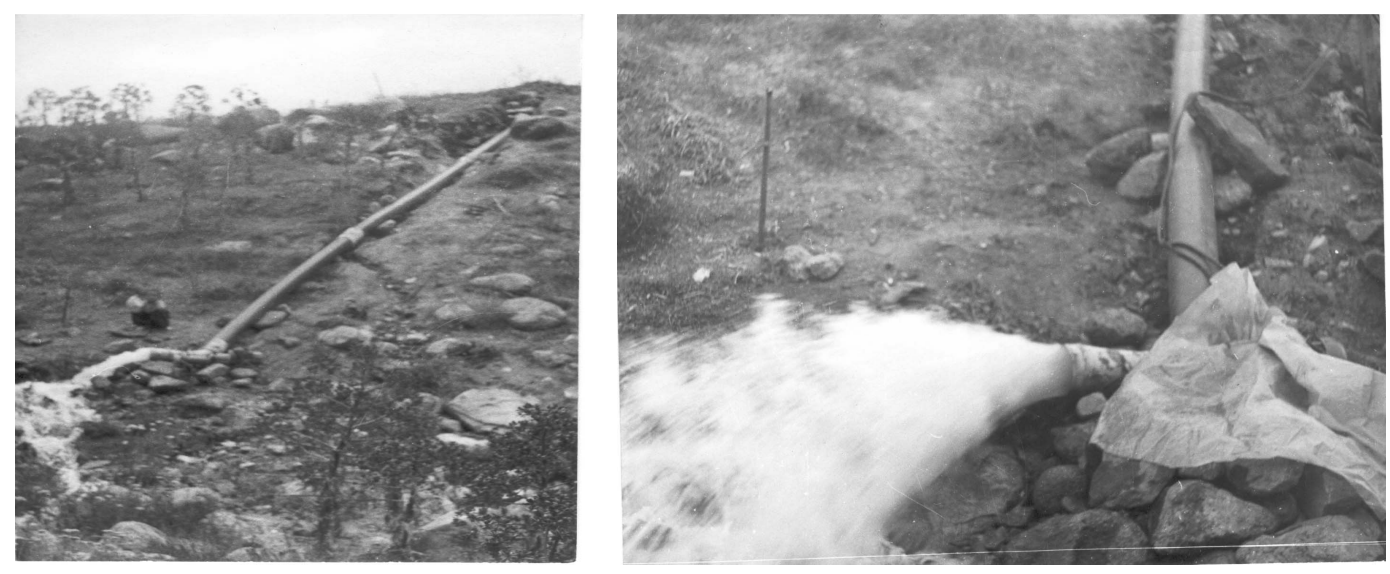

Fig. 1: Micro-hydro-electric power station installed in the village named PashmiKukhna.

The tests of the micro-hydropower system showed that for a water head of 4-6 m, station was not working well even at the load power of $0.1-0.2 \mathrm{~kW}$ in each phase. After this the water head was increased up to 10-12 m, it provides stable operation of the station at different loads. During tests, angular velocity of the generator's shaft was controlled by a tachometer. At an angular velocity of almost 3000 RPM, self-excitation of the generator was observed which confirmed that the output voltage and rotor's angular velocity relationship is non-linear for the asynchronous generators. The successful operation of the micro-hydropower system replaced the kerosene lamps into electric lamps at all nine houses at the village. Later on a similar type of micro-hydropower plant was installed in the village Hakimi in the same district.

For the economic evaluation of a MHP system, the parameters that are usually considered are [14]: life-cycle cost (LCC), payback period (PP) and rate of return (RR). LCC is the sum of all the costs of a system over its lifetime, expressed in today's money. For the analysis of the MHPs, the lifetime of the MHP can be taken as 10 years. For a detailed analysis, it is important to use parameters including: present worth (PW) which is the equivalent value in today's economy of the future costs (future cost should be multiplied by a discount factor calculated from a discount rate), period of analysis (the lifetime of the longest-lived system under comparison), excess inflation (the rate of price' increase of a component above general inflation), discount rate (the rate at which money would increase in value if invested), capital cost (the total initial cost of buying and installing the system), operation and maintenance (the amount spent each year in keeping the system operational) and replacement cost (the cost of replacing each component at the end of its lifetime). The calculations are made on the basis of the approach described in reference [14]:

$$
P W=C r x P r
$$

where $P W$ is the present worth for a single future payment, $\mathrm{Cr}$ is a single future cost, $\mathrm{Pr}$ is discount factor for a single future payment. In the case of repeating payments [5]:

$$
P W=C a x P a
$$


where $P W$ is the present worth for annual future payment, $\mathrm{Ca}$ is annual future cost and $\mathrm{Pa}$ is a discount factor for annual future payment. The $\mathrm{Pa}$ and $\mathrm{Pr}$ is determined as [14];

$$
\begin{aligned}
& \operatorname{Pr}=[(1+i) /(1+d)]^{N} \\
& \text { and } \quad P a=[(1+i) /(1+d)] \cdot\left\{[(1+i) /(1+d)]^{N}-1\right\} /\{[(1+i) /(1+d)]-1\}
\end{aligned}
$$

where $N$ is the period of analysis, $d$ is discount rate and $i$ is excess inflation ( it is "the rate of price increase of a component above or below general inflation that is usually assumed to be zero" [14]) .

The annualized life-cycle cost (ALCC) is determined as $=\mathrm{LCC} / \mathrm{Pa}$

The $P r$ and $P a$ can be found using tables presented in [14]. Table 2 shows life-cycle costing calculation for the micro-hydropower plant installed in the village Pashmi-Kukhna of Tajikistan.

Table 2: Life-cycle costing calculation of MHP installed in the village Pashmi-Kukhna of Tajikistan.

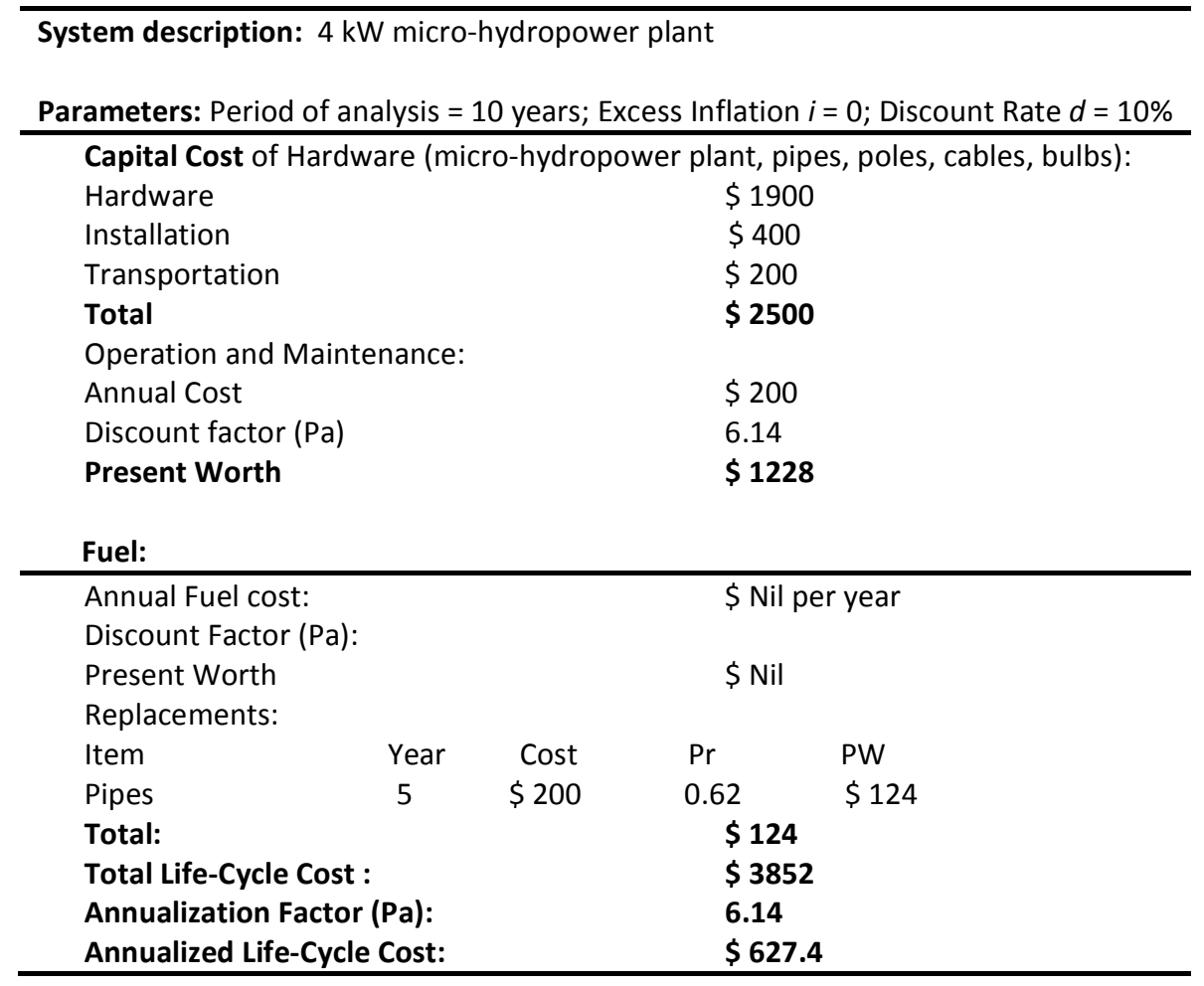

Assuming that micro-hydropower plant is working 16 hours a day during 350 days in a year, Electricity produced per year $(\mathrm{kWh})=4 \mathrm{~kW} \times 16 \mathrm{hr} \times 350 \times 0.9=20160(\mathrm{kWh})$

Efficiency of transmission lines assumed is almost $90 \%$.

Electricity cost $(\$ / \mathrm{kWh})=627.4(\$) / 20160(\mathrm{kWh})=0.03(\$ / \mathrm{kWh})=3 \mathrm{Cent} / \mathrm{kWh}$.

It is known that for small and large hydropower plants the cost of electricity is in the range of 3-10 Cent/kWh and 2-5 Cent/kWh respectively [15]. 


\section{ECONOMICS OF BATTERY-BASED MICRO-HYDROPOWER PLANT ON CATAMARAN FOR FREE WATER FLOW OPERATION DESIGNED IN GIK INSTITUTE OF PAKISTAN}

Micro-hydropower plants for free water flow operation provide unique chance to use hydropower of canals and small rivers where no waterfalls or sufficient large water heads is available. In this case only kinetic energy of water flow can be converted into electric power. As battery based micro-hydropower systems can operate and store energy continuously, almost 24 hours per day, electric energy produced daily will be sufficient for the main electric and electronic appliances of an average family.

The battery-based micro-hydropower systems with storage of electric energy in the electrochemical batteries are economically advantageous to use if the peak load is considerably larger than the hydropower plant [1]. In this case hydro power is converted into electric power using micro-hydropower system and stored in the batteries and is used during shorter time at peak/maximum load. The batteries in this case undergo deep discharge of up to $50 \%$ of their total capacity and after that these are charged. The battery-based micro-hydropower systems belong to the systems that are not connected with the grid and can work jointly with photo-voltaic and wind power plants on common load. This type of system is called as hybrid system. The battery-based micro-hydropower systems as compared to the AC-direct micro-hydropower systems have the advantage as they can work at relatively low water flow rates but at the same time being able to provide the necessary peak power in the load when it is required [1]. Block-diagram of the batterybased micro-hydropower system is shown in Fig. 2. It is assumed that a DC generator is used however if an $\mathrm{AC}$ generator is used then an alternating current should be rectified by a rectifier. As seen from block-diagram (Fig. 2) the battery-based micro-hydropower systems can feed DC loads directly from batteries and AC loads are fed through an inverter. If the DC voltage exceeds nominal value in the input of the battery, the charge regulator turns on ballast loads, providing normal charging regime of the battery.

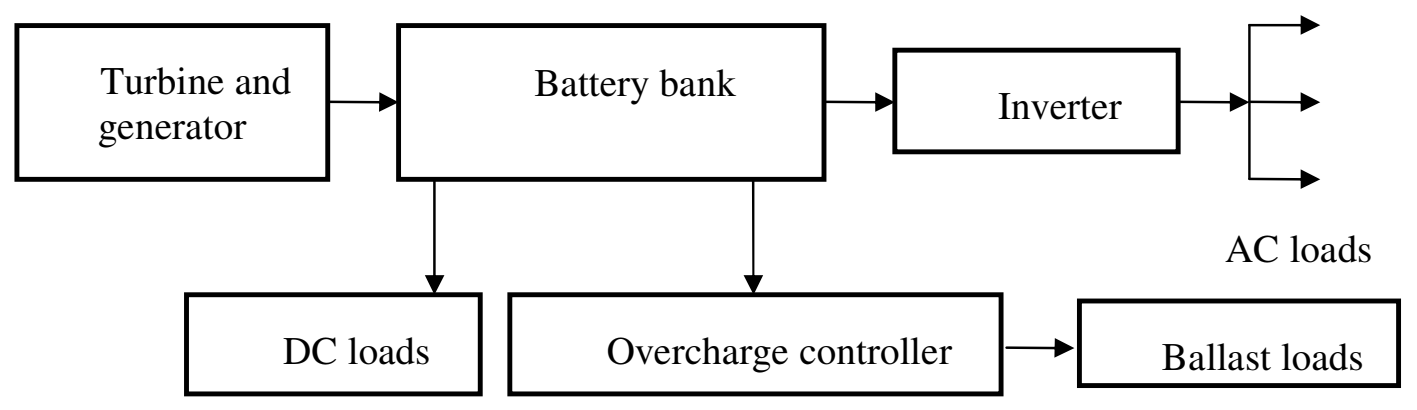

Fig. 2: Block-diagram of the battery-based micro-hydropower systems.

It is noted that the battery-based micro-hydropower systems can provide a peak power in the load that is much more than the installed power of the system. For example, the battery-based micro-hydropower system of power of $400 \mathrm{~W}$ can provide $5 \mathrm{~kW}$ peak power at the corresponding capacity of the batteries. The industry produces battery-based micro-hydropower systems for DC voltage of 12, 24, 36, 48, 120 and $240 \mathrm{~V}$. Selection of output voltage depends on the power of the micro-hydropower systems and the distance between of generator and consumer: as the distance is larger the voltage should be higher to decrease the losses in the power transmission lines. There are commercially available 
battery-based micro-hydropower systems from power of $100 \mathrm{~W}$ to $1600 \mathrm{~W}$. In Table 3, data on mechanical and electrical parameters and properties of battery-based microhydropower systems are given [1]. These micro-hydropower systems are adapted for operation in autonomous regime.

In some countries floating, barge or catamaran micro-hydropower systems are used where the turbine and generator are installed on the small raft that is fixed by ropes to the bank of river or canal as shown in Fig. 3. Figure 4 shows battery-based micro-hydropower plant of power of $1 \mathrm{~kW}$ on catamaran for free water flow operation designed and fabricated in GIK Institute of Pakistan. This battery-based micro-hydropower plant on catamaran has three turbines (wheels) blades having phase angle of $15-25^{\circ}$ from each other to provide uniform rotation of the turbines shaft. Table 3 shows parameters and properties of the battery-based micro-hydropower systems.

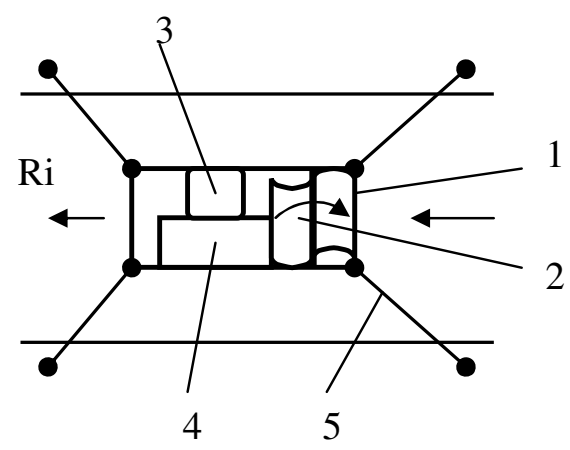

Fig. 3: Floating micro-hydropower system: 1-raft, 2-turbine, 3-generator, 4-reducer, 5rope.

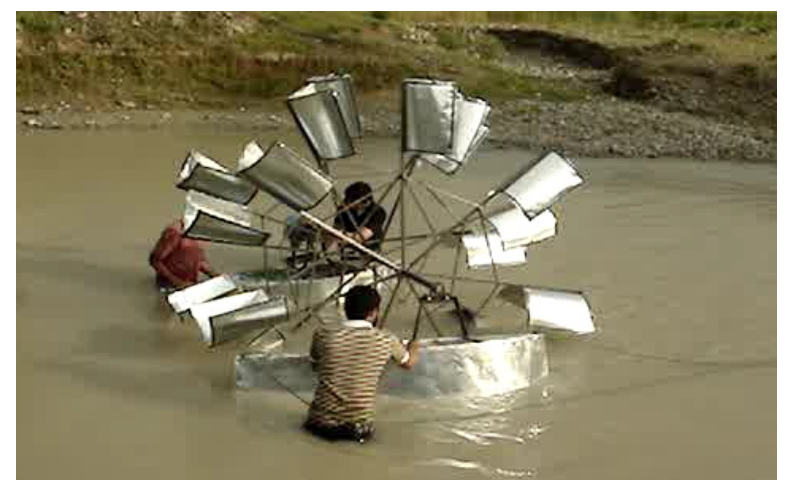

Fig. 4: Battery-based micro-hydropower plant on catamaran for free water flow operation designed and fabricated in GIK Institute of Pakistan.

The battery-based micro-hydropower systems with storage of electric energy in the electrochemical batteries are economically advantageous to use if the peak load is considerably larger than the hydropower. In this case the hydro power is converted into electric power using micro-hydropower system and stored in the batteries and is used during short time at peak/maximum load. The battery based micro-hydropower systems can operate and store energy continuously, almost 24 hours per day. Table 4 shows lifecycle costing calculation sheet for battery-based micro-hydropower plant on catamaran for free water flow operation designed and fabricated in GIK Institute of Pakistan. 
Table 3: Parameters and properties of the battery-based micro-hydropower systems.

\begin{tabular}{|c|c|c|c|c|c|}
\hline Systems & $\begin{array}{c}\text { Output } \\
\text { power } \\
(W)\end{array}$ & $\begin{array}{c}\text { Head } \\
(\mathbf{m})\end{array}$ & $\begin{array}{c}\text { Flow rate } \\
\left(\mathrm{m}^{3} / \mathbf{s}\right)\end{array}$ & $\begin{array}{c}\text { DC voltage } \\
\text { (V) }\end{array}$ & $\begin{array}{c}\text { Type of } \\
\text { turbine and } \\
\text { generator }\end{array}$ \\
\hline Very low head & $100-1000$ & $1-3$ & $0.03-0.065$ & $12 / 24 / 48 / 120$ & $\begin{array}{l}\text { Propeller. } \\
\text { Permanent magnet } \\
\text { DC generator }\end{array}$ \\
\hline $\begin{array}{l}\text { Low and } \\
\text { medium head }\end{array}$ & $50-1600$ & $3-60$ & $0.0006-0.01$ & $12 / 24 / 48 / 120$ & $\begin{array}{c}\text { Turgo. } \\
\text { Permanent magnet } \\
\text { DC generator }\end{array}$ \\
\hline High head & $100-1500$ & $6-180$ & $0.00025-0.016$ & $12 / 48$ & $\begin{array}{c}\text { Pelton. } \\
\text { Permanent magnet } \\
\text { DC generator }\end{array}$ \\
\hline Water current & 100 & flowing & 0.25 & $12 / 24$ & $\begin{array}{l}\text { Propeller. } \\
\text { Submersible } \\
\text { generator }\end{array}$ \\
\hline
\end{tabular}

Table 4: Life-cycle costing calculation sheet for battery-based micro-hydropower plant on catamaran for free water flow operation designed in GIK Institute of Pakistan.

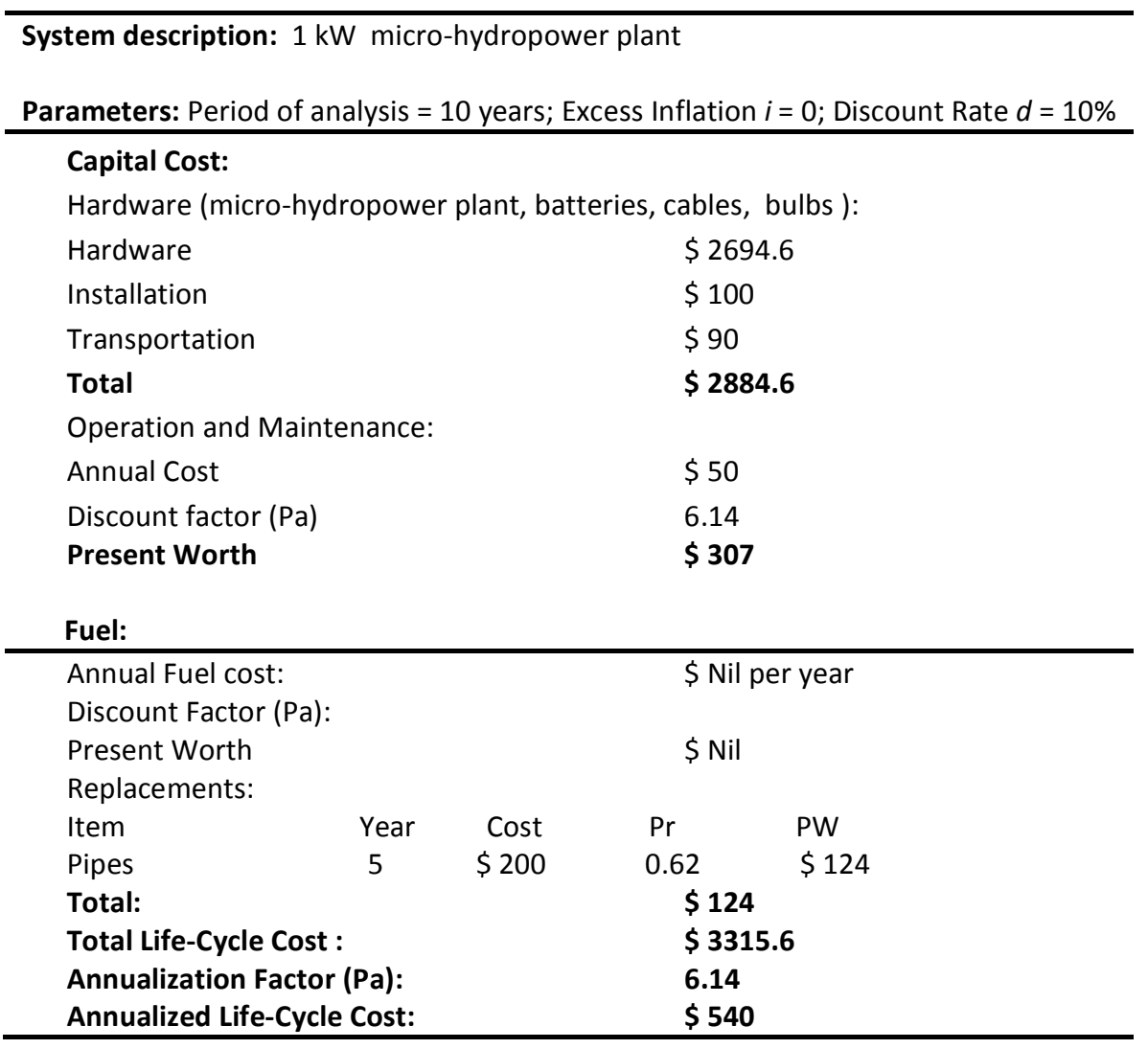


Assuming that micro-hydropower plant is working 24 hours a day during 350 days in a year, Electricity produced per year $(\mathrm{kWh})=1 \mathrm{~kW} \times 24 \mathrm{hr} \times 350 \times 0.9 \times 0.75=5672$ $(\mathrm{kWh})$.

Taking efficiencies of battery and transmission lines of $75 \%$ and $90 \%$ respectively.

Electricity cost $(\$ / \mathrm{kWh})=540(\$) / 5672(\mathrm{kWh})=0.1(\$ / \mathrm{kWh})=10 \mathrm{Cent} / \mathrm{kWh}$.

It is known for small and large hydropower plants the cost of electricity is in the range of 3-10 Cent $/ \mathrm{kWh}$ and 2-5 Cent $/ \mathrm{kWh}$ respectively [15].

In this paper, expenses including cost of design, rent of land, license of land, unpredictable expenses, investigation of feasibility of the project, rent of water may also be considered in the capital cost as in above calculations these costs are nt considered.

\section{CONCLUSION}

The unit electricity cost determined from the life-cycle cost and annual life-cycle cost analysis is the main parameter in the economics of the renewable energy resources equipment and in particular, in the micro-hydropower systems. Calculations showed that the costs of the electric energy generated by the MHPs installed in Tajikistan and Pakistan is almost 3 and 10 cent $/ \mathrm{kWh}$ respectively. The cost of the micro-hydropower plants can be reduced by using state of the art technology, cost effective generators and turbines as these are the most expensive parts in MHP and by controlling the cost of construction. Similarly cost can be controlled by using induction motors as generators and pumps as turbines. The calculation of the electricity cost done in this paper may be considered as an internal cost. The calculations of the hydropower electricity should also include the external cost including environmental (cost of risks of damages to the environment and human health due to pollutions) and non-environmental costs (costs are associated with employment, security aspects etc). Considering external costs, hydropower will be more economical and attractive as compared to the non-renewable sources. Catastrophes and land effects are much less for the micro-hydropower systems compared to the large power hydro-electric systems. However only visual intrusion can be taken into consideration. It is therefore concluded that the future development of the micro-hydropower systems can bring more environmental and economical benefits as compared to the larger power energy technologies.

\section{ACKNOWLEDGEMENT}

The authors are thankful to authority of GIK Institute of Pakistan and Academy of Sciences of Tajikistan for the support of the projects. Authors also grateful to researchers, technicians and students of both organizations for their help in completing these projects.

\section{REFERENCES}

[1] Neally, Christpher, and Ian Verstuyft. Micro-Hydropower Systems. A Buyer's Guide. Natural Resources, Canada, 2004

[2] United.States. Dept of Energy. National Renewable Energy Laboratory. Small Hydropower Systems .washington,2001.

[3] United .States. Dept of Energy. Office of Energy Efficiency and Renewable Energy. Consumer Energy Information: EREC Reference Briefs. Is a Micro-Hydroelectric System Feasible for You? November 2002.

[4] Avakyan A.B.. Hydropower Resources. Nauka, Moscow, 1967. 
[5] Artyukh S.F., Panteleeva I.V. Universities News. Power Engineering, 5(1990):24-28.

[6] Alekseenko V.N., Korablev A.D. "Transportable hose-pipe micro-hydropower system." Construction of rural electric power systems, Informenergo, Moscow, Russia,.5, (1978).

[7] Gudnov Yu.V. "Potentialities of small hydropower system construction, Power system abroad." 2 (1981):32-38.

[8] Ezhkov A.V. "Equipment of micro-hydropower systems, Power system abroad." 5(1982):35-37

[9] Zirakadze N.I. "Velocity controller for micro-hydropower systems." (1971).

[10] Ivanov A.A. "Asynchronous generators for hydropower systems." Gosenergoizdat, Moscow, Leningrad, Russia,( 1958).

[11] Karimov U.Kh., Karimov Kh.S. "On utilization of the micro-hydropower system in Tajikistan mountain regions." Geliotechnika, 4 (1998):87-90.

[12] "Manual of the micro-hydropower system manufactured by Turbine Constructing Industrial Union "Leningrad Metallic Plant.", St.-Petersburg, Russia, 1990.

[13] Abid Muhammad, Khasan Karimov. "Micro-Hydropower Systems. Utilization of Hydropower." VDM Verlag, Dr.Muller,Aktiengesellschaft \& Co.KG and lisensors, (2010).

[14] Markvart, Tomas .Solar Electricity.., John Wiley \& Sons 2000.

[15] http://www.greenworldinvestor.com 